\title{
Identification and quantification of notch receptors in human cutaneous melanoma using molecular biology techniques: literature review
}

\author{
Lorena Dal Collina Sangiuliano, Renato Santos de Oliveira Filho* (D), Daniel Arcuschin de Oliveira, \\ Heitor Carvalho Gomes and Lydia Masako Ferreira
}

\begin{abstract}
Background: The Notch signaling pathway and its modulators are directly related to growth, verticalization and metastasis in melanoma, being a possible therapeutic target for the treatment of this type of cancer. There are several methods of molecular biology to identify and quantify Notch receptors and it is essential to study them for understanding the different results, advantages and disadvantages of each.

Main body: The present study brings a bibliographic review on the molecular biology methods used in the identification and quantification of these molecules, aiming to facilitate research involving Notch receptors in human melanoma. We identified as main methods of molecular biology Western Blotting, Quantitative real-time polymerase chain reaction and DNA microarrays. A brief description of these methodologies is made and the advantages and disadvantages of each are discussed. Results concerning the function of this pathway are also discussed.

Short conclusion: It is known that the activation of Notch receptors is tumorigenic in most cases, however, depending on the microenvironment, it can provide tumor suppression. The adequate choice and use of the methodology for identification and quantification of Notch receptors is essential for the progress of knowledge of this important signaling pathway, which, certainly, will allow advances in the treatment of cutaneous melanoma.
\end{abstract}

Keywords: Notch, Melanoma, Molecular biology, Western blotting, qRT-PCR, Microarrays

\section{Background}

Notch receptors are integral transmembrane proteins composed of an extracellular Notch domain (ECD), an intracellular Notch domain (ICD) and a single transmembrane domain that joins the two previous structures. In mammals, these receptors are expressed by four different genes (Notch 1-4), originating the respective 4 receptors and respond to justacrine - type signaling of 5 types of ligands, which are also integral transmembrane proteins (Delta-like 1,3 and 4 - ligands, Jagged-1 and 2) (Yamamoto 2019).

\footnotetext{
* Correspondence: universoemexpansao@gmail.com

Federal University of São Paulo (UNIFESP), São Paulo, SP, Brazil
}

When the Notch receptor binds to one of the 5 ligands, the receptor is cleaved by the metalloprotease TACE (Tumor necrosis factor- $\alpha$-converting enzyme), releasing the ECD that will be degraded, and by the $\gamma$-secretase complex, which releases the active Notch domain, the ICD, a transcriptional co-activator that will be directed to the nucleus by the adapter protein importin- $\alpha$ (Nickoloff et al. 2003; Kopan 2012; Huenniger et al. 2010).

The canonical Notch signaling pathway involves the helix-loop-helix transcription factor CSL (recombination signal binding protein for immunoglobulin kappa J), a transcriptional repressor that acts as a DNA binding adapter. The formation of the ICD-CSL complex leads to the recruitment of several elements of transcriptional

(c) The Author(s). 2020 Open Access This article is licensed under a Creative Commons Attribution 4.0 International License, which permits use, sharing, adaptation, distribution and reproduction in any medium or format, as long as you give

appropriate credit to the original author(s) and the source, provide a link to the Creative Commons licence, and indicate if changes were made. The images or other third party material in this article are included in the article's Creative Commons licence, unless indicated otherwise in a credit line to the material. If material is not included in the article's Creative Commons licence and your intended use is not permitted by statutory regulation or exceeds the permitted use, you will need to obtain permission directly from the copyright holder. To view a copy of this licence, visit http://creativecommons.org/licenses/by/4.0/. 
activation, such as MAML (Mastermind like) and p300, which will act on the Notch target genes, such as the HEY and HES genes (Takebe et al. 2014; Oliveira Filho et al. 2019).

Notch signaling can result in tumor suppression or oncogenesis. The diversity of signaling results is determined by the concomitant existence of transcription activators and repressors in the signaling cascade and by the context in which the tumor is inserted, which includes interaction of the Notch pathway with other pathways, such as protein kinase B (AKT) and mitogen-activated protein kinase (MAPK) pathways, genetic changes and the microenvironment in which the tumor is inserted (Takebe et al. 2014; Ayaz and Osborne 2014; Zeng et al. 2005; Oliveira Filho et al. 2019; Reichrath and Reichrath 2020).

Certainly, the Notch signaling pathway is necessary for normal epithelial development. However, abnormal Notch signaling has already been associated with development, growth, angiogenesis and metastasis in melanoma. (Hendrix et al. 2002; Curtin et al. 2005; Garraway 2014; Takebe et al. 2014; Bedogni 2014; Golan et al. 2015; Krepler et al. 2016; Oliveira Filho et al. 2019).

In 2018, according to the International Agency for Research on Cancer, 287,723 new cases of melanoma were diagnosed and 60,712 deaths occurred due to it, the most lethal of skin cancers. The Institute estimates a $62 \%$ increase in the incidence of melanoma by 2040 , with a possibility of 466,914 new cases that year, and a $74 \%$ increase in melanoma mortality, with a possibility of 105,904 deaths (IARC (a) 2018; IARC (b) 2018).

Among the genetic mutations associated with melanoma it is the activation of BRAF and N-RAS oncogenes, which correspond to $81 \%$ of the mutations associated with melanoma and which are associated with aberrant Notch activation (Curtin et al. 2005; Garraway 2014; Krepler et al. 2016).

The study and understanding of the Notch signaling pathway in melanoma is essential, since its manipulation has a high therapeutic potential for the treatment of melanoma and other cancers and is directly correlated with the resistance of tumor cells to drugs (Wang et al. 2010; Liu et al. 2014).

Molecular biology techniques are one of the most used means to analyze the Notch signaling pathway. In general terms, molecular biology techniques are those that study the interactions of DNA, RNA, protein synthesis and the regulation of these interactions. There are few studies that analyze these methods and their results, none directly related to the evaluation of these methodologies in the analysis of Notch signaling in melanoma.

This article makes a bibliographic review on the ways of identification and quantification of Notch in human cutaneous melanoma using molecular biology techniques. We contrasted and examined different methodologies, analyzing their results to establish the state of knowledge in this area, with the aim of connecting theory to practice.

\section{Main text}

After approval by the Unifesp Research and Ethics Committee, articles published between 2015 and 2020 that used molecular biology methods to identify and quantify Notch receptors in human cutaneous melanoma were searched and selected in the Medline, Lilacs and Google Scholar databases, as well as references cited in these articles published from the year 2000 onwards. Descriptors used: Notch; melanoma; molecular biology; Western Blotting; qRT-PCR and Microarrays. Articles of uveal melanoma were excluded. Each selected article was summarized, tables and graphs were built and submitted to a detailed study by the authors, integrating everyone's analysis.

Twenty-eight articles were analyzed, with nine different methodologies for analyzing the expression of Notch receptors associated with melanoma, in decreasing order of use: 78.6\% (22/28) articles used Western Blotting (WB); $42.8 \%(12 / 28)$ Quantitative real-time polymerase chain reaction (qRT-PCR); 35.7\% (10/28) DNA microarrays (DMA); 7.1\% (2/28) Green Fluorescent Protein in Recombinant DNA technique; 3.6\% (1/28) Polymerase chain reaction (PCR); $3.6 \%(1 / 28)$ Semiquantitative polymerase chain reaction; 3.6\% (1/28) Electrophoretic Mobility Shift Assay; 3.6\% (1/28) Chromatin immunoprecipitation and $3.6 \%(1 / 28)$ Northern Blot. One study used PCR Array, which uses the techniques of qRT-PCR and DMA, so this work was counted as using both techniques.

Among the Notch receptors, the most analyzed was the Notch 1 (N1) receptor, explored in 78.6\% (22/28) articles, the only one being explored in $39.3 \%(11 / 28)$ of them and the main receptor explored in $46,4 \%(13 / 28)$ of them. The other receptors, Notch 2 (N2), 3 and 4, were analyzed in $53.6 \%(15 / 28), 35.7 \%(10 / 28)$ and $35.7 \%(10 / 28)$ of the articles, respectively; however, they were explored as the main research recipient in only $17.9 \%(5 / 28), 7.1 \%(2 / 28)$ and $10.7 \%(3 / 28)$ of the articles, respectively. The main way to analyze Notch receptors was in its active form, ICD, which was used in $62.3 \%(18 / 28)$ of the articles, however, messenger RNA (mRNA), proteins, transmembrane domain, the Notch coding gene, among other ways, were also used. It is important to note that the analysis of target genes or Notch ligands were used in most of the analyzed articles (22/28 or 78.6\%) for the analysis of the Notch signaling pathway.

The studies used two means to obtain the melanoma cells to be subjected to the experiments. They used preestablished cell lines, with characteristics already known, which can be purchased or obtained from other researchers, or used material obtained from metastatic and primary tumors of living human patients through biopsies. For primary melanoma, excisional biopsies are best for histopathological diagnosis (Smith et al. 2020) and for providing substrate to be used in molecular biology techniques. For metastatic lesions, core biopsy is sufficient, being a less invasive method (Smith et al. 2020). 
The use of the fine needle aspiration method has already shown viable results for obtaining human melanoma cells for culture (Oliveira et al. 2005); however, for diagnosis and obtaining of material for analysis by molecular biology, the core biopsy of the metastatic lesion is more appropriate.

The characteristics, advantages and disadvantages of each of the three most used molecular biology methods (WB, qRT-PCR and DMA) are discussed below.

\section{Western blotting or immunoblotting}

Technique for identifying specific proteins, even if not very abundant, using specific antibodies labeled with radioactive isotopes, easily detectable enzymes or fluorochromes, after fractionization of the target protein in polyacrylamide gel (Alberts et al. 2010; Kurien and Scofield 2015).

The process begins with the separation of proteins by electrophoresis in polyacrylamide gel. First, the sample is treated with a negatively charged detergent, usually sodium dodecyl sulfate, which causes proteins to turn into extended polypeptide chains and to shut down from other proteins or lipids molecules. Other reagents are added to the sample, some for total separation of the polypeptides and, finally, a dye is added, so that the bands formed after electrophoresis are visible to the naked eye. It is important to quantify the proteins in the sample, since for their efficient separation and for obtaining good results it is essential to respect the limited capacity of the polyacrylamide gel to house these polypeptides (Alberts et al. 2010; Hnasko and Hnasko 2015).

A gel electrophoresis is then performed. Passing an electric current through the gel, the migration of proteins will occur. Proteins will separate according to their molecular mass: the negatively charged detergent binds to proteins of the same size in the same quantity, which causes them to migrate at the same speed from the negative to the positive pole. Larger proteins, despite being subjected to more intense electrical forces, suffer a greater delay by the gel, which has the size of their pores adjusted for this purpose, and migrate slowly, so that the bands formed by them are closer to the negative pole. The migration of proteins results in the formation of bands whose size will depend on the quantity of protein it contains. Results will be spurious if the polypeptide chain has many carbohydrates (Alberts et al. 2010; Hnasko and Hnasko 2015).

The next step is known as blotting, when occurs the transference of proteins from the gel to microporous membranes, which can be as varied as possible, such as nitrocellulose paper or nylon membranes. The transference to membranes allows some advantages over the gel, since wet membranes are flexible and easy to handle and they allow easy access of proteins to different ligands, multiple transfers from the same gel, longer storage time and successive analyzes from a single membrane.
Blotting can be done using various techniques, which include simple diffusion, vacuum suction and electrical transference (Alberts et al. 2010; Kurien and Scofield 2015).

The membrane is then placed in a solution with the labeled antibody that will show, if it is present, the presence of the target protein. There are two methods of adding antibodies: direct and indirect. In the direct method, only the labeled antibody is added to the solution and in the indirect one, after the addition of a specific non-labeled antibody for the protein, a labeled antispecific antibody is added, which will bind to the first antibody, denouncing the presence of the specific enzyme-first antibody binding (Cann 2005; Alberts et al. 2010). The indirect method was the most used in the analyzed articles.

For linkage analysis, strategies are used to identify the component used to label the antibody. This step may require the use of high-cost laboratory equipment (Alberts et al. 2010; Gorr and Vogel 2015; Kurien and Scofield 2015), what can be a limiting factor for the use of WB.

Even though it is a widely-used technique, in the analyzed articles the most used one, and it has a high efficiency, primarily because of its high sensitivity, WB presents some limitations. The antibodies and laboratory equipment to analyze antibodies - substrate binding can be expensive, those antibodies can bind to proteins that are not the target ones and sometimes they cannot identify the target protein, because of its extreme variable nature, for example, they cannot identify denatured proteins. Furthermore, WB requires a high expertise from the researcher: depending on who performs it, its results can present an $80 \%$ difference. For example, inappropriate blotting can lead to a great inefficiency of the whole experiment, its efficiency can be increased by the proper choice of gel's thickness, membrane type and by other means; protein quantification must be properly done to avoid membrane's pores saturation, what can also compromise the results and a proper choice of the detection and amplification method used at the end of the process must be done. However, most limitations can be avoided taking the necessary care so that the technique is performed correctly (Ghosh et al. 2014; Gorr and Vogel 2015; Kurien and Scofield 2015).

\section{Quantitative real-time polymerase chain reaction}

qRT-PCR is a technique that allows the amplification and quantification of specific genetic material, beginning with the whole cell mRNA population (Williams 2019; Alberts et al. 2010; Martin 2019).

The method starts with a sample containing the total mRNA population of the cell or tissue analyzed and must not contain DNA, which needs to be degraded. The mRNA is transcribed in complementary DNA 
(cDNA), using the enzyme reverse transcriptase, a primer and deoxyribonucleotide triphosphates. Then, the two strands are separated by heating (denaturation), followed by the addition of the second type of primer, which will generate the complementary sequence to the cDNA. Chemical dyes, fluorochromes (TaqMan probe) or radioisotopes and biotin (hybridization probe) are added to the reaction, which appear only when bound to DNA, therefore the need for the initial DNA of the sample to be eliminated, to avoid errors in quantification (Freerman et al. 1999; Williams 2019; Alberts et al. 2010; Hawkins and Guest 2017).

Then the same procedure used in the PCR technique is proceeded, in which several cycles of denaturation, annealing and elongation are repeated. Each cycle begins with denaturation by heating the sample, which allows the strands to separate. Then, in the presence of a large excess of primers, the annealing is carried out, a cooling of the sample, which allows the primers to hybridize with the complementary sequences to be cloned. This mixture is then incubated with DNA polymerase and desoxyribonucleosides, thus elongation begins: the synthesis of the cloned DNA begins with the primers and the strand is extended. In the next cycles, the same process is followed and, in addition to the genome template, the new DNA synthesized in the previous PCR cycles will be used as a template for new clones, so that the process is exponential. In a few cycles, the product of the cloned fragment will predominate, all the same length, corresponding to the distance between the two original primers. The whole process requires 20 to 30 cycles and lasts a few hours (Freerman et al. 1999; Alberts et al. 2010).

The real-time quantitative process is based on a direct relationship between the generation speed of the PCR product and the original concentration of the mRNA of interest. For calculation purposes, it is necessary that, along with the reaction, a control reaction is performed, which allows knowing data on the efficiency of the process steps (Freerman et al. 1999; Alberts et al. 2010; Martin 2019).

qRT-PCR has great advantages over PCR and RT-PCR: it is more accurate, guarantees the researcher quantitative results without the need for association with other techniques, allows analysis of multiple genes from the same sample and it is less prone to contamination of the sample, since the whole process takes place in a closed tube that does not need to be opened after the reaction (Williams 2019).

While WB is mainly used for translational products, that is, proteins, qRT-PCR is used mainly for transcriptional products, that is, mRNA. After transcription, mRNA undergoes post-transcriptional modifications and regulation, whereas proteins undergo post-translational changes and degradation, which results in different levels of mRNA and protein of the same gene (Alberts et al. 2010), therefore, the ideal is to use the methodologies together. The preference for WB relating to qRT-PCR, probably derived from the fact that $\mathrm{WB}$ is cheaper and allows to evaluate the results of the pathway activity, proteins, whose levels are already influenced by other factors adjacent to the context surrounding the cell.

As for the advantages of qRT-PCR relating to DMA, it is that its quality and dynamic range are much higher than that of DMA (Williams 2019), however, the techniques can be combined to obtain better results.

\section{DNA microarrays}

DMA is a technique that allows the analysis of the differential gene expression and copy number variations (CNVs) of thousands of genes simultaneously, in different situations to which the cell can be submitted, besides allowing the analysis of clusters, that is, the pattern of joint expression of genes whose products are correlated with the same specific cell function (Alberts et al. 2010; Mcinnes et al. 2016).

The technique consists in analyzing slides of glass or silicone perforated extensively by microarrays: large quantities of DNA fragments, of known position in the slide, containing nucleotide sequences that serve as a probe for a specific gene. These microarrays can be, among other techniques, prepared from PCR and then plotted on the slide using robotic printing (Alberts et al. 2010; Harel and Lupski 2017).

First the mRNA of the studied cell is extracted and converted to cDNA using the enzyme reverse transcriptase, then this cDNA is labeled with fluorescent probes. The sample is then incubated with the microarray. The cDNAs, derived from the sample mRNAs, which hybridize with a probe in the array, can be identified as a product of the specific gene represented by that probe. Generally, next to the sample, incubation of control cDNA marked with fluorochromes of another color is made. CNVs, deletions and duplications, size and known genes can be identified on chromosomes (Alberts et al. 2010; Zhang et al. 2017; Mcinnes et al. 2016).

The technique is highly sensitive and even allows to identify such small changes in the expression of genes that do not cause phenotypic changes in the cell. In addition, it allows the analysis of thousands of genes simultaneously; it is automated, with little influence by the scientist's ability to develop the technique and its results have high resolution. However, the technique has some limitations, for example, it is expensive; the quality and quantity of mRNAs and tissue samples can interfere with the results; only available arrangements can be analyzed, which limits the exploration of the expression pattern of the entire genome. In addition, the quality of the results depends on the researcher's ability to analyze the data generated, which is not perfectly standardized, although many algorithms already exist for its analysis 
(Alberts et al. 2010; Zhang et al. 2017; Harel and Lupski 2017; Russo et al. 2003; Kusuma and Kodabagi 2020).

DMA were used in the studies analyzed mainly to identify several genetic alterations at once, being able to evaluate the ones involved in melanoma and those that occur together with alterations in Notch expression. In this way, DMA allows the evaluation of the cell's genetic material, but not the direct changes that the cellular context will produce in the Notch pathway. Anyway, the analysis of altered genes along with altered Notch expression allows to guide the researcher in which genes to study to solve the problem-question that he proposes.

\section{Notch signaling pathway results in the analyzed studies}

Elevated Notch 1-4 expression was identified in several cell lines analyzed in different studies (Mikheil et al. 2019; Hartman et al. 2019; Skarmoutsou et al. 2018; Tang et al. 2019; Hubmann et al. 2017; Lin et al. 2016; Howard et al. 2013; Zhang et al. 2012; Hardy et al. 2010; Huynh et al. 2011; Gast et al. 2010; Jönsson et al. 2007; Hoek et al. 2004; Bedogni et al. 2008). The metastatic strains showed higher levels of Notch 1 expression than the primary strains and it was almost imperceptible or null in normal melanocytes (Golan et al. 2015; Zhang et al. 2012). Notch 1 was also associated with resistance to MAPK inhibitors (MAPKi) in BRAFV600E melanoma cells, its increased expression, along with the maximum expression of Notch 3 and 4, was found in cells resistant to MAPKi with reduced activation of phosphatase and tensin homolog (PTEN) and increased activation of phosphatidylinositol-3-kinase (PI3K) (Krepler et al. 2016). However, another study demonstrated reduced Notch 1 levels in BRAFV600E melanoma cells resistant to MAPKi and its forced expression led to the reduction of endothelin 1 (EDN1) expression, through c-JUN, resulting in apoptosis of resistant cells (Mikheil et al. 2019).

Elevated levels of Notch 3 and 4 expression were associated with a more aggressive melanoma phenotype, being highly elevated in stem-like melanoma cells (MSLC) and in melanoma cells co-cultured with endothelial cells (Hsu et al. 2017; Lin et al. 2016; Howard et al. 2013; Hardy et al. 2010).

Only in 2 of the 28 studies, Notch receptors acted as tumor suppressors, in the others it revealed an oncogenic role (promotion of cell proliferation, metastasis, angiogenesis and vasculogenic mimicry). Notch's role as a tumor suppressor may be one of the reasons why $\gamma$ secretase inhibitors (GSI) are deficient in the treatment of metastatic melanoma (Rad et al. 2016).

Notch's role as a tumor suppressor could be identified by the fact that the forced expression of $\mathrm{N} 1^{\mathrm{ICD}}$ alone is sufficient to induce apoptosis in mutated BRAFV600E melanoma cells resistant and not resistant to MAPKi. Apoptosis occurs by reducing the expression of EDN1, by c-JUN, induced by Notch 1 (Mikheil et al. 2019). In addition, Notch 4 has also been described as a tumor suppressor for its role in the mesenchymal-epithelial transition (MET), which leads to reduced motility, proliferation and invasive phenotype in melanoma in vitro and reduced tumorigenicity in vivo (Rad et al. 2016).

The growth, survival and acquisition of more aggressive tumor phenotype generated by Notch 1 is mediated by beta-catenin (Balint et al. 2005) and by the MAPK and PI3K/AKT pathways, which are activated indirectly in an event dependent on the transcription mediated by the Notch/MAML cascade (Liu et al. 2006) and, for PI3K/ $\mathrm{AKT}$, also by the positive regulation of neuregulin 1 (NRG1) by Notch1 (Zhang et al. 2012). The inhibition of Notch 1 and epidermal growth factor receptor (ERBB), which binds to NRG1, regulated by Notch 1, activating the AKT pathway, attenuates the signaling of tumor growth and survival factors AKT and nuclear factor kappa $\mathrm{B}$, whose subunits p65 and p50 are retained in the cytosol, what blocks its transcriptional activity and inhibits the population of cells positive for lysine-specific demethylase $5 \mathrm{~B}$, a critical element for the long-term maintenance of melanoma growth (Zhang et al. 2012; Zhang et al. 2016). Furthermore, the negative regulation of Notch 1, through the inhibition of epidermal growth factor like domain 7 , is a mechanism that induces apoptosis and inhibits cell proliferation (Tang et al. 2019).

The high expression of BRAF-activated non-protein coding RNA (BANCR), characteristic of melanoma, leads to the inhibition of micro RNA (miR)-204, a negative regulator of Notch 2, what results in the activation of this receptor. This BANCR/miR-204/Notch2 axis intermediates cell proliferation, tumor progression, invasiveness capability and protection against apoptosis (Cai et al. 2017).

The expression of miR-146a inhibits the expression of NUMB (repressor of the Notch signaling pathway), increasing the expression of Notch. MiR-146a is highly regulated by oncogenic BRAF and N-RAS. Inhibition of miR-146a results in reduced proliferation and tumor formation in melanoma, probably due to the consequent Notch inhibition (Forloni et al. 2014).

Notch 3 and 4 receptors still act on oncogenesis by promoting angiogenesis and vasculogenic mimicry (VM). Notch3, intermediates cell-cell contact between endothelial and melanoma cells, which can lead to the induction of the MSLC phenotype (highly resistant), angiogenesis and VM (Hsu et al. 2017). Notch 4 has also been identified as a promoter of angiogenesis and VM both in MSLCs and in human cutaneous melanoma cells (Lin et al. 2016; Hardy et al. 2010).

In addition, Notch receptors have been associated with the epithelial-mesenchymal transition (EMT) of cells, which gives them greater mobility and invasive capacity. Notch4 (+) MSLCs trigger EMT in melanoma cells, with increased 
expression of Twist-related protein 1, vascular endothelial cadherin and reduced expression of epithelial cadherin, inducing metastasis (Lin et al. 2016; Hoek et al. 2004).

The contact of melanoma cells with differentiated keratinocytes activates Notch signaling. The translocation of ICD to the nucleus results in the removal of the inducing transcription factor (MITF)/CSL repressor from the miR-222/221 promoter, whose expression allows the acquisition of the invasion capacity, which does not depend exclusively on genetic alterations, but also on the microenvironment in which the melanoma is inserted, activating Notch signaling (Golan et al. 2015).

Opposite roles of Notch signaling, such as promoting both EMT and MET, being oncogenic and a tumor suppressor, being associated with resistance and sensitivity to MAPKi, among other contrasts that affect the results of Notch signaling, depend on several factors, among which are the tumor's microenvironment, genetic factors associated with different melanoma cell lines and interaction of Notch signaling with other signaling pathways.

As for the microenvironment, the interaction of endothelial and melanoma cells and melanoma and keratinocyte cells produce different effects on Notch signaling, as previously described (Hsu et al. 2017; Golan et al. 2015; Howard et al. 2013). In addition, hypoxia also contributes to melanoma oncogenesis, as it stabilizes hypoxia inducible factor- $1 \alpha$, increasing levels of Notch1 (Bedogni et al. 2008).

Each tumor is affected by major and most common somatic genetic changes, such as changes in Notch, BRAF, N-RAS, ERBB, MITF, carotenoid cleavage dioxygenase 1, murine double minute 2, PTEN; and by specific genetic changes, which can produce different results in Notch signaling in each cell line (Gast et al. 2010; Jönsson et al. 2007). For example, the $\mathrm{NOTCH} 2^{\mathrm{F} 1209 \mathrm{~V}}$ and $\mathrm{NOTCH} 2{ }^{\mathrm{N} 2002 \mathrm{~S}}$ variants have opposite activity: HES1 expression was significantly lower in cells with the F1209V variant and significantly higher in cells with the N2002S variant, what can produce significant phenotypic differences in the cell (Hartman et al. 2019).

Genetic differences in each stage of development of melanoma (radial, vertical and metastatic) produce different results in Notch signaling. The role of Notch 1 was identified as stage specific, predominating in primary melanomas, mainly in the phase of vertical growth, leading the melanoma to a more aggressive phenotype, acquiring metastatic ability. Despite being present in higher concentrations in metastatic melanoma cells, as mentioned earlier, Notch 1 does not alter cell morphogenesis or proliferation at this stage (Liu et al. 2006; Balint et al. 2005; Golan et al. 2015). In addition, melanoma cells co-cultured with endothelial cells showed different changes in Notch 3 modulation, higher in melanoma cells in the vertical growth phase and lower in those in radial phase. Although all metastatic melanoma cells have increased Notch 3 mRNA expression, the increase was more expressive in cells in the vertical phase (Howard et al. 2013). Overexpression of mutated BRAF resulted in reduced expression of ICD and HES1 proteins only in metastatic melanoma cells, reinforcing Notch's specific stage role (Maddodi et al. 2010).

Considering that Notch 3 expression is higher in vertical phase, high levels of Notch 3 can be considered evidence of a worse prognosis in patients with melanoma (Howard et al. 2013). Still on the prognosis, another study showed that high levels of HES1 and delta-like 3 ligand expression, components of Notch signaling, are significantly associated with reduced post-recurrence melanoma survival (Huynh et al. 2011). Forkhead box protein P3 (FOXP3) has also been described as a marker of aggression and metastasis and it is regulated by Notch 1 in two ways: directly raising FOXP3 transcription and cooperatively with TGFB1, which is also responsible for increasing Notch 1 expression (Skarmoutsou et al. 2018).

Notch interactions with other pathways producing different results have already been described. It is also worth noting that Notch 4 in aggressive cell lines is a positive regulator of Nodal, which is partly responsible for VM and independent anchorage growth produced by Notch 4 in melanoma (Hardy et al. 2010). Another important interaction is the regulation of the Notch pathway by BRN2, pathway activator, and by MITF, pathway repressor; high levels of MITF can reduce the expression of BRN2, reducing the expression of Notch (Thurber et al. 2011).

Rad and collaborators attest that GSI has not been showing efficient results, what may be related to Notch's role as a tumor suppressor ( $\operatorname{Rad}$ et al. 2016). Studies using GSI have shown a reduction in Notch signaling, but the success in tumor suppression, however, depended on other factors associated with the context in which the melanoma cells analyzed were inserted. In studies that used the GSI RO4929097, there was a reduction in the capacity of cell proliferation and invasion and in Notch expression levels (Nair et al. 2013; Huynh et al. 2011). However, only cells with wild PTEN showed induction of senescence and apoptosis, with wild PTEN being an important sensitivity factor for this GSI (Nair et al. 2013). Yet, GSI Dibenzazepine together with Lapatib (tyrosine kinase inhibitor that inhibits ERBB3/2), in cells with mutated BRAF and N-RAS, reduced cell viability by $90 \%$, hindering tumor growth and inducing apoptosis of melanoma cells (Zhang et al. 2016).

Other studies have evaluated the efficiency of drugs, not previously characterized as GSIs. Gliotoxin could induce apoptosis, reduced tumor volume and prevented the formation of the $\mathrm{N} 2{ }^{\mathrm{ICD}}$-DNA complex, being considered more efficient than GSI DAPT (Hubmann et al. 2017). Phospholipase A2 derived from the Daboia 
siamensis venom (dssPLA2) demonstrated cytotoxicity in melanoma cells, with increased apoptosis, reduced migration capacity and, after $72 \mathrm{~h}$, reduced Notch1 levels, which was associated with the induction of death and cell damage caused by dssPLA2 (Khunsap et al. 2016). Finally, the natural biphenolic compound Hokoniol (HNK) reduced levels of $\mathrm{N} 1^{\mathrm{ICD}}$ and $\mathrm{N} 2^{\mathrm{ICD}}$ expression, by inhibiting the expression of TACE and $\gamma$ secretase complexes, thus reduced proliferation, viability, clonogenicity and induced autophagy, but not apoptosis, were observed in melanoma cells. In addition, HNK was a potent inhibitor of MSCLs (Kaushik et al. 2015).

\section{Conclusion}

The study and understanding of Notch signaling in melanoma is essential, since manipulation of the pathway has high therapeutic potential for treating melanoma and other cancers and since Notch is directly associated with tumor cell resistance to drugs (Wang et al. 2010; Liu et al. 2014).

Notch is directly related to melanoma, either as a tumor suppressor (rarely) or promoter. Divergent results in the studies demonstrate the complexity of this type of skin cancer, which is not strictly determined by the Notch signaling pathway, and depends on the context in which the cells are inserted, such as the tumor microenvironment, genetic factors associated with melanoma and pathways that interact with each other. Knowing that, it can be inferred that each patient's tumor genetics and specific conditions can be analyzed and used as an important tool to choose the most suitable treatment for each individual, aiming better results.

Given the opposition between Notch signaling results, depending on the context in which the cell is inserted, it is necessary to use extremely reliable methods for its quantitative and qualitative analysis by molecular biology, to avoid that results contrary to those of previously published studies are just the result of error in the execution of the methodology and ensure that they are a new way in which the Notch pathway acts on melanoma, in variable contexts. Therefore, it is essential that experimental studies are carried out to compare the efficiency of the different molecular biology methods in the analysis of Notch in melanoma, focusing on the 3 main methods used: WB, qRT-PCR and DMA.

The choice of the methodology to be used depends on the objectives and possibilities of the researchers. However, the joint use of several methodologies can guarantee more reliable and reproducible results.

According to the results of our review, WB seems to be the most proper molecular biology technique to be used to analyze the Notch signaling pathway in melanoma, and to test therapies' influence on it. Besides the fact it was the primarily mean chosen by researches to analyze Notch on their studies, WB allows the analysis of proteins, which are the result of the pathway activity, revealing any influences on the final product of the gene. Messengers RNA undergo post-transcriptional modifications thus, the analysis of proteins, using WB, should be the most adequate to analyzes all the medium's and therapeutics' influence on the cell, acknowledging posttranscriptional and post-translational changes, that can alter the results of the modulation of the Notch signaling pathway in the melanoma.

\section{Abbreviations \\ AKT: Protein kinase B; BANCR: BRAF-activated non-protein coding RNA; CDNA: Complementary DNA; CNV: Copy number variations; \\ CSL: Recombination signal binding protein for immunoglobulin kappa J; DMA: DNA microarrays; dssPLA2: Phospholipase A2 derived from Daboia siamensis venom; ECD: Extracellular Notch Domain; EDN1: Endothelin 1; EMT: Epithelial mesenchymal transition; ERBB: Epidermal growth factor receptor; FOXP3: Forkhead box protein P3; GSI: $ү$-secretase inhibitor; HNK: Hokoniol; ICD: Intracellular Notch Domain; MAML: Mastermind-like; MAPK: Mitogen-activated protein kinase; MAPKi: MAPK inhibitor; MET: Mesenchymal epithelial transition; miR: Micro RNA; MITF: Melanocyte inducing transcription factor; mRNA: Messenger RNA; MSLCs: Melanoma stem-like cells; N1: Notch 1; N2: Notch 2; NRG1: Neuregulin 1; \\ PCR: Polymerase chain reaction; PI3K: Phosphatidylinositol-3-kinase; PTEN: Phosphatase and tensin homolog; qRT-PCR: Quantitative real-time polymerase chain reaction; TACE: Tumor necrosis factor-a-converting en- zyme; VM: Vasculogenic mimicry; WB: Western Blotting}

\section{Acknowledgements \\ Not applicable.}

\section{Authors' contributions}

LDCS provided the search of the main subject in databases; analyzed and summarized each one of the articles producing tables and graphs of their content and drafted the base manuscript in Portuguese. RSOF conceived the study, participated in the selection of the analyzed articles and participated in the design and coordination of the study. DAO participated in the organization of the text for publication and in the content analysis, translation and final revision of the manuscript. HCG and LMF participated in the sequence alignment and final revision. All authors read and approved the final manuscript.

\section{Funding}

None.

Availability of data and materials Not applicable.

Ethics approval and consent to participate Not applicable.

\section{Consent for publication}

Not applicable.

\section{Competing interests}

The authors declare that they have no competing interests.

Received: 5 June 2020 Accepted: 30 July 2020

Published online: 27 August 2020

\section{References}

Alberts B, Johnson A, Lewis J, Morgan D, Raff M, Roberts K et al (2010) Biologia molecular da célula, 6th edn. Artmed Editora, Porto Alegre

Ayaz F, Osborne BA (2014) Non-canonical Notch signaling in cancer and immunity. Front Oncol. https://doi.org/10.3389/fonc.2014.00345 
Balint K, Xiao M, Pinnix C, Soma A, Veres I, Juhansz I et al (2005) Activation of Notch 1 signaling is required for beta-catenin-mediated 6 human primary melanoma progression. J Clin Invest. https://doi.org/10.1172/JCI25001

Bedogni B (2014) Notch signaling in melanoma: interacting pathways and stromal influences that enhance notch targeting. Pigment Cell Melanoma Res. https://doi.org/10.1111/pcmr.12194

Bedogni B, Warneke JA, Nickoloff BJ, Giaccia AJ, Powell MB (2008) Notch1 is an effector of Akt and hypoxia in melanoma development. J Clin Invest. https:// doi.org/10.1172/JCl36157

Cai B, Zheng Y, Ma S, Xing Q, Wang X, Yang B et al (2017) BANCR contributes to the growth and invasion of melanoma by functioning as a competing endogenous RNA to upregulate Notch2 expression by sponging miR-204. Int J Oncol. https://doi.org/10.3892/ijo.2017.4173

Cann A (2005) Introduction: serological/immunological methods. In: Cann A (ed) Principles of molecular virology. Elsevier Academic Press, Londres, pp 9-12

Curtin JA, Fridlyand J, Kageshita T, Patel HN, Busam KJ, Kutzner H et al (2005) Distinct sets of genetic alterations in melanoma. N Engl J Med. https://doi. org/10.1056/NEJMoa050092

Forloni M, Dogra SK, Dong Y, Conte D Jr, Ou J, Zhu LJ et al (2014) miR-146a promotes the initiation and progression of melanoma by activating Notch signaling. Elife. https://doi.org/10.7554/eLife.01460

Freerman WM, Walker SJ, Vrana KE (1999) Quantitative RT-PCR: pitfalls and potential. Biotechniques. https://doi.org/10.2144/99261rv01

Garraway LA (2014) A Notch for noncoding RNA in melanoma. N Engl J Med. https://doi.org/10.1056/NEJMcibr1402173

Gast A, Scherer D, Chen B, Bloethner S, Melchert S, Sucker A et al (2010) Somatic alterations in the melanoma genome: a high-resolution array-based comparative genomic hybridization study. Genes Chromosom Cancer. https://doi.org/10.1002/gcc.20785

Ghosh R, Jeniffer GE, Gomes VA (2014) The necessity of and strategies for improving confidence in the accuracy of western blots. Expert Rev Proteomics. https://doi.org/10.1586/14789450.2014.939635

Golan T, Messer AR, Amitai-Lange A, Melamed Z, Ohana R, Bell RE et al (2015) Interactions of melanoma cells with distal keratinocytes trigger metastasis via Notch signaling inhibition of MITF. Mol Cell. https://doi.org/10.1016/j.molcel. 2015.06.028

Gorr TA, Vogel J (2015) Western blotting revisited: critical perusal of underappreciated technical issues. Proteomics Clin Appl. https://doi.org/10. 1002/prca.201400118

Hardy KM, Kirschmann DA, Seftor EA, Margaryan NV, Postovit LM, Strizzi L, Hendrix MJ (2010) Regulation of the embryonic morphogen nodal by Notch4 facilitates manifestation of the aggressive melanoma phenotype. Cancer Res. https://doi.org/10.1158/0008-5472

Harel T, Lupski JR (2017) Genomic disorders 20 years on-mechanisms for clinical manifestations. Clin Genet. https://doi.org/10.1111/cge.13146

Hartman ML, Sztiller-Sikorska M, Czyz M (2019) Whole-exome sequencing reveals novel genetic variants associated with diverse phenotypes of melanoma cells. Mol Carcinog. https://doi.org/10.1002/mc.22953

Hawkins SFC, Guest PC (2017) Multiplex analyses using real-time quantitative PCR. Methods Mol Biol. https://doi.org/10.1007/978-1-4939-6730-8_8

Hendrix MJ, Seftor RE, Seftor EA, Gruman LM, Lee LM, Nickoloff BJ et al (2002) Transendothelial function of human metastatic melanoma cells: role of the microenvironment in cell-fate determination. Cancer Res 62:665-668

Hnasko TS, Hnasko RM (2015) The Western blot. Methods Mol Biol. https://doi. org/10.1007/978-1-4939-2742-5_9

Hoek K, Rimm DL, Williams KR, Zhao H, Ariyan S, Lin A et al (2004) Expression profiling reveals novel pathways in the transformation of melanocytes to melanomas. Cancer Res. https://doi.org/10.1158/0008-5472.CAN-04-0731

Howard JD, Moriarty WF, Park J, Riedy K, Panova IP, Chung CH et al (2013) Notch signaling mediates melanoma-endothelial cell communication and melanoma cell migration. Pigment Cell Melanoma Res. https://doi.org/10. 1111/pcmr.12131

Hsu MY, Yang MH, Schnegg Cl, Hwang S, Ryu B, Alani RM (2017) Notch3 signaling-mediated melanoma-endothelial crosstalk regulates melanoma stem-like cell homeostasis and niche morphogenesis. Lab Investig. https:// doi.org/10.1038/labinvest.2017.1

Hubmann R, Sieghart W, Schnabl S, Araghi M, Hilgarth M, Reiter M et al (2017) Gliotoxin targets nuclear Notch2 in human solid tumor derived cell lines in vitro and inhibits melanoma growth in xenograft mouse model. Front Pharmacol. https://doi.org/10.3389/fphar.2017.00319
Huenniger K, Krämer A, Soom M, Chang I, Köhler M, Depping R et al (2010) Notch1 signaling is mediated by importins alpha 3, 4, and 7. Cell Mol Life Sci. https://doi.org/10.1007/s00018-010-0378-7

Huynh C, Poliseno L, Segura MF, Medicherla R, Haimovic A, Menendez S et al (2011) The novel gamma secretase inhibitor RO4929097 reduces the tumor initiating potential of melanoma. PLoS One. https://doi.org/10.1371/journal. pone.0025264

IARC (a) (2018) Global cancer observatory, cancer today. https://gco.iarc.fr/today. Accessed 11 Feb 2020

IARC (b) (2018) Global cancer observatory, cancer tomorrow. https://gco.iarc.fr/ tomorrow Accessed 11 Feb 2020

Jönsson G, Dahl C, Staaf J, Sandberg T, Bendahl PO, Ringnér M et al (2007) Genomic profiling of malignant melanoma using tiling-resolution arrayCGH. Oncogene. https://doi.org/10.1038/sj.onc.1210252

Kaushik G, Venugopal A, Ramamoorthy P, Standing D, Subramaniam D, Umar S et al (2015) Honokiol inhibits melanoma stem cells by targeting notch signaling. Mol Carcinog. https://doi.org/10.1002/mc.22242

Khunsap S, Khow O, Buranapraditkun S, Suntrarachun S, Puthong S, Boonchang S (2016) Anticancer properties of phospholipase $A_{2}$ from Daboia siamensis venom on human skin melanoma cells. J Venom Anim Toxins Incl Trop Dis. https://doi.org/10.1186/s40409-016-0061-z

Kopan R (2012) Notch signaling. Cold Spring Harb Perspect Biol. https://doi.org/ 10.1101/cshperspect.a011213

Krepler C, Xiao M, Samanta M, Vultur A, Chen HY, Brafford P et al (2016) Targeting Notch enhances the efficacy of ERK inhibitors in BRAF-V600E melanoma. Oncotarget. https://doi.org/10.18632/oncotarget.12078

Kurien BT, Scofield RH (2015) Western blotting: an introduction. Methods Mol Biol. https://doi.org/10.1007/978-1-4939-2694-7_5

Kusuma B, Kodabagi MM (2020) Analysis of microarray data for identification differentially expressed genes: a survey. https://doi.org/10.2139/ssrn.3563567 Available at SSRN: https://ssrn.com/abstract=3563567Accessed: 05 May 2020

Lin X, Sun B, Zhu D, Zhao X, Sun R, Zhang Y, Zhang D et al (2016) Notch4+ cancer stem-like cells promote the metastatic and invasive ability of melanoma. Cancer Sci. https://doi.org/10.1111/cas.12978

Liu J, Fukunaga-Kalabis M, Li L, Herlyn M (2014) Developmental pathways activated in melanocytes and melanoma. Arch Biochem Biophys. https://doi. org/10.1016/j.abb.2014.07.023

Liu ZJ, Xiao M, Balint K, Smalley KS, Brafford P, Qiu R et al (2006) Notch1 signaling promotes primary melanoma progression by activating mitogen-activated protein kinase/phosphatidylinositol 3-kinase-Akt pathways and up-regulating N-cadherin expression. Cancer Res. https://doi.org/10.1158/0008-5472.CAN05-3589

Maddodi N, Bhat KM, Devi S, Zhang SC, Setaluri V (2010) Oncogenic BRAFV600E induces expression of neuronal differentiation marker MAP 2 in melanoma cells by promoter demethylation and down-regulation of transcription repressor HES1. J Biol Chem. https://doi.org/10.1074/jbc.M109.068668

Martin J (2019) Updating PCR. Biotechniques. https://doi.org/10.2144/btn-20190076

Mcinnes RR, Willard HF, Nussbaum R (2016) Thompson \& Thompson genética médica, 8th edn. Elsevier Brasil, Rio de Janeiro

Mikheil DM, Prabhakar K, Arshad A, Rodriguez Cl, Newton MA, Setaluri V (2019) Notch signaling activation induces cell death in MAPKi-resistant melanoma cells. Pigment Cell Melanoma Res. https://doi.org/10.1111/pcmr.12764

Nair JS, Sheikh T, Ho AL, Schwartz GK (2013) PTEN regulates sensitivity of melanoma cells to RO4929097, the $\gamma$-secretase inhibitor. Anticancer Res 33(4): $1307-1316$

Nickoloff BJ, Osborne BA, Miele L (2003) Notch signaling as a therapeutic target in cancer: a new approach to the development of cell fate modifying agents. Oncogene. https://doi.org/10.1038/sj.onc.1206758

Oliveira A, Gragnani A, Oliveira Filho RS, Santos ID, França SG, Enokihara MM et al (2005) Modelo experimental de cultura primária de melanoma metastático por punção aspirativa de agulha fina. Acta Cir Bras. https://doi.org/10.1590/ S0102-86502005000500009

Oliveira Filho RS, Soares AL, Paschoal FM, Rezze GG, Oliveira E, Macarenco R et al (2019) Literature review of Notch melanoma receptors. Surg Exp Pathol. https://doi.org/10.1186/s42047-019-0052-9

Rad EB, Hammerlindl H, Wels C, Popper U, Menon DR, Breiteneder H et al (2016) Notch4 signaling induces a mesenchymal-epithelial-like transition in melanoma cells to suppress malignant behaviors. Cancer Res. https://doi.org/ 10.1158/0008-5472.CAN-15-1722 
Reichrath J, Reichrath S (2020) Notch pathway and embryonic development: an ancient friend, revisited. Adv Exp Med Biol. https://doi.org/10.1007/978-3-03034436-8_2

Russo G, Zegar C, Giordano A (2003) Advantages and limitations of microarray technology in human cancer. Oncogene. https://doi.org/10.1038/sj.onc. 1206865

Skarmoutsou E, Bevelacqua V, D'Amico F, Russo A, Spandidos DA, Scalisi A et al (2018) FOXP3 expression is modulated by TGF- $\beta 1 /$ NOTCH1 pathway in human melanoma. Int J Mol Med. https://doi.org/10.3892/ijmm.2018.3618

Smith N, Johnson TM, Kelly JW, Sober AJ, Bichakjian C (2020) Biopsy of suspected melanoma. In: Balch C et al (eds) Cutaneous melanoma. Springer, Cham. https://doi.org/10.1007/978-3-030-05070-2_10

Takebe N, Nguyen D, Yang SX (2014) Targeting Notch signaling pathway in cancer: clinical development advances and challenges. Pharmacol Ther. https://doi.org/10.1016/i.pharmthera.2013.09.005

Tang H, Xiao WR, Liao YY, Li L, Xiao X, Xu XP et al (2019) EGFL7 silencing inactivates the Notch signaling pathway; enhancing cell apoptosis and suppressing cell proliferation in human cutaneous melanoma. Neoplasma. https://doi.org/10.4149/neo_2018_180310N167

Thurber AE, Douglas G, Sturm EC, Zabierowski SE, Smit DJ, Ramakrishnan SN (2011) Inverse expression states of the BRN2 and MITF transcription factors in melanoma spheres and tumour xenografts regulate the NOTCH pathway. Oncogene. https://doi.org/10.1038/onc.2011.33

Wang Z, Li Y, Ahmad A, Azmi AS, Banerjee S, Kong D et al (2010) Targeting Notch signaling pathway to overcome drug resistance for cancer therapy. Biochim Biophys. https://doi.org/10.1016/.jbbcan.2010.06.001

Williams M (2019) Real-time polymerase chain reaction. In: Bustin S (ed) The PCR revolution: basic technologies and applications. Cambridge University Press, Cambridge, pp 3-11

Yamamoto S (2019) Making sense out of missense mutations: mechanistic dissection of Notch receptors through structure-function studies in drosophila. Develop Growth Differ. https://doi.org/10.1111/dgd.12640

Zeng Q, Li S, Chepeha D, Giordano T, Li J, Zhang H et al (2005) Crosstalk between tumor and endotelial cells promotes tumor angiogenesis by MAPK activation of Notch signaling. Cancer Cell. https://doi.org/10.1016/..ccr.2005. 06.004

Zhang C, Cerveira E, Romanovitch M, Zhu Q (2017) Array-based comparative genomic hybridization (aCGH). Cancer Cytogenetics. https://doi.org/10.1007/ 978-1-4939-6703-2_15

Zhang K, Wong P, Salvaggio C, Salhi A, Osman I, Bedogni B (2016) Synchronized targeting of Notch and ERBB signaling suppresses melanoma tumor growth through inhibition of Notch1 and ERBB3. J Invest Dermatol. https://doi.org/ 10.1016/i.jid.2015.11.006

Zhang K, Wong P, Zhang L, Jacobs B, Borden EC, Aster JC, Bedogni B (2012) A Notch1-neuregulin1 autocrine signaling loop contributes to melanoma growth. Oncogene. 2012. https://doi.org/10.1038/onc.2011.606

\section{Publisher's Note}

Springer Nature remains neutral with regard to jurisdictional claims in published maps and institutional affiliations.

Ready to submit your research? Choose BMC and benefit from:

- fast, convenient online submission

- thorough peer review by experienced researchers in your field

- rapid publication on acceptance

- support for research data, including large and complex data types

- gold Open Access which fosters wider collaboration and increased citations

- maximum visibility for your research: over $100 \mathrm{M}$ website views per year

At $\mathrm{BMC}$, research is always in progress.

Learn more biomedcentral.com/submissions 